\title{
Penerapan Storytelling dalam Menceritakan Kisah Alkitab pada Anak Sekolah Minggu
}

\author{
I Putu Ayub Dharmawan'1, Kiki Priskila² \\ 1,2Sekolah Tinggi Teologi Simpson, Ungaran, Jawa Tengah \\ ${ }^{1}$ putuayub.simpson@gmail.com, ${ }^{2}$ kkpriskila@gmail.com
}

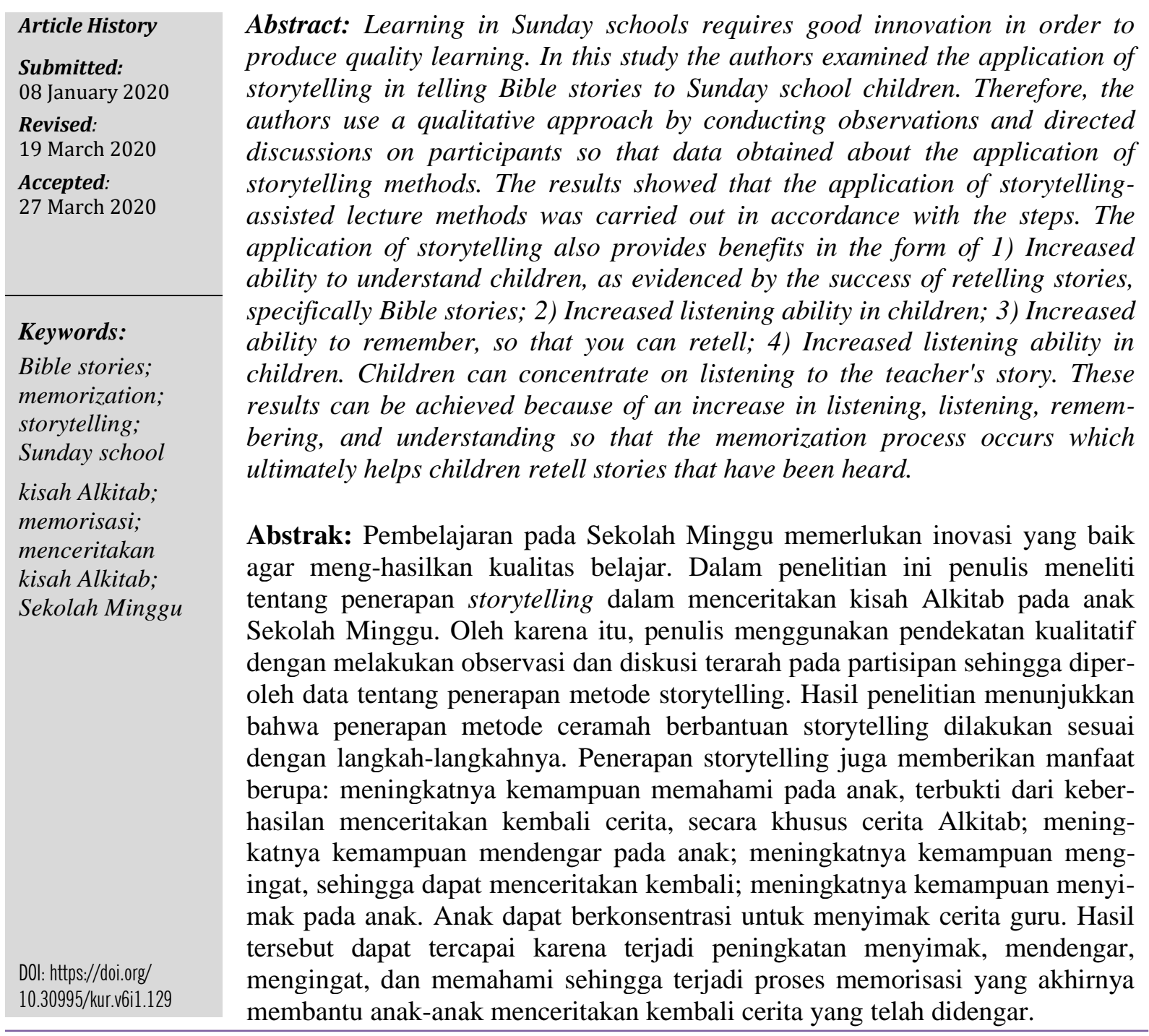

\section{Pendahuluan}

Istilah storytelling berasal dari dua kata yaitu story (cerita) dan tell (menceritakan) merupakan salah satu model pembelajaran dengan menyampaikan cerita kepada para pendengar yang dapat mengembangkan imajinasi dan tidak menggurui. ${ }^{1}$ Dalam penelitian Ningsih tampak jika

${ }^{1}$ Rita Diah Ayuni, S. Siswati, and Diana Rusmawati, "Pengaruh Storytelling Terhadap Perilaku Empati Anak," Jurnal Psikologi 12, no. 2 (2013): 122. 
model pembelajaran cerita memiliki manfaat untuk meningkatkan keterampilan berbicara pada anak. ${ }^{2}$ Melalui metode ini anak dapat tertarik kemudian mengingat kosakata dan menceritakan kembali apa yang telah didengarnya. Penelitian Anjani, Wirya, dan Sudatha menunjukkan bahwa metode bercerita efektif untuk meningkatkan kemampuan kognitif anak. Hal ini terbukti dari penelitian yang dilakukan di PAUD Pradnya Paramita, Kecamatan Buleleng. ${ }^{3}$ Demikian pula penelitian Anggrayeni, Suarni, dan Ambara menunjukkan bahwa metode cerita mampu untuk meningkatkan keterampilan berbicara pada anak. Dari penelitian yang dilaksanakan pada sebuah taman bermain anak-anak di Singaraja, menunjukkan bahwa metode cerita memiliki efektivitas untuk meningkatkan kemampuan berbicara pada anak. ${ }^{4}$ Sementara untuk penelitian yang meneliti model pembelajaran storytelling pada anak sekolah dasar yang dilakukan oleh Safira, Riastini, dan Dibia menunjukkan bahwa pembelajaran ini membantu untuk meningkatkan kemampuan berbicara pada anak-anak. ${ }^{5}$ Pendekatan ini tampaknya efektif menolong anak-anak yang dalam pertumbuhannya membutuhkan banyak kosakata untuk direkam dan disimpan. Penelitian Faridawati, Eliyawati, dan Rudiyanto juga menunjukkan bahwa metode pembelajaran storytelling mampu untuk meningkatkan kemampuan berbicara pada anak-anak. Kemampuan tersebut dapat meningkat karena anak mulai merekam, meniru, menyusun kalimat sederhana sehingga akhirnya dapat meningkatkan kemampuan berbicara anak. ${ }^{6}$

Dalam observasi penulis pada beberapa Sekolah Minggu, model pembelajaran ini umum digunakan di pembelajaran Sekolah Minggu dan sesuai dengan materi yang akan disampaikan. Materi Sekolah Minggu adalah cerita-cerita Alkitab yang mengandung nilainilai kehidupan dan moral. Melalui cerita Alkitab yang disampaikan, peserta Sekolah Minggu dapat membangun imajinasi dan daya ingat. Permatasari, Inten, Mulyani, dan Rahminawati menjelaskan bahwa orang dewasa memiliki tanggung jawab untuk membantu anak-anak memperoleh informasi atas dunia dan identitasnya. Pemenuhan tersebut dapat dilakukan dengan cerita, sebab melalui cerita, kebutuhan anak pada informasi atas dunia dan identitasnya sebagai manusia akan terpenuhi. ${ }^{7}$

Sekolah Minggu yang dilaksanakan di setiap hari Minggu adalah suatu kegiatan ibadah Kristen yang bertujuan untuk mengajarkan Alkitab dan nilai-nilai Kristen kepada anak-anak

\footnotetext{
${ }^{2}$ Suwarti Ningsih, "Peningkatan Keterampilan Berbicara Melalui Metode Bercerita Siswa Kelas III SD Negeri 1 Beringin Jaya Kecamatan Bumi Raya Kabupaten Morowali,” Jurnal Kreatif Online 2, no. 4 (2015): 243-256.

${ }^{3}$ Ketut Sri Anjani, I. Nyoman Wirya, and I. Gde Wawan Sudatha, "Penerapan Metode Bercerita Berbantuan Media Papan Flanel Untuk Meningkatkan Kemampuan Kognitif Pada Anak Kelompok A Di PAUD Pradnya Paramita," Jurnal Pendidikan Anak Usia Dini Undiksha 1, no. 1 (2013): 1-10.

${ }^{4}$ Ni Komang Anggrayeni, Ni Ketut Suarni, and Didith Pramunditya Ambara, "Penerapan Metode Bercerita Berbantuan Media Audio Visual Untuk Meningkatkan Keterampilan Berbicara Anak," Jurnal Pendidikan Anak Usia Dini Undiksha 3, no. 1 (2015), accessed January 4, 2020, https://ejournal.undiksha.ac.id/index.php/JJPAUD/article/view/5896.

${ }^{5}$ Alifia Nur Safira, Putu Nanci Riastini, and I Ketut Dibia, "Pengaruh Teknik Pembelajaran Storytelling Berbantuan Satua Bali Terhadap Keterampilan Berbicara Pada Siswa Kelas V SD," MIMBAR PGSD Undiksha 5, no. 2 (2017): 1-10.

${ }^{6}$ Ria Faridawati, Cucu Eliyawati, and Rudiyanto Rudiyanto, "Meningkatkan Kemampuan Berbicara Anak Usia Dini Melalui Metode Bercerita Menggunakan Media Hasil Karya Anak," Edukids: Junal Pertumbuhan, Perkembangan, dan Pendidikan Anak Usia Dini 14, no. 1 (2017): 208-213.

${ }^{7}$ Andalusia Neneng Permatasari et al., "Literasi Dini Dengan Teknik Bercerita," FamilyEdu: Jurnal Pendidikan Kesejahteraan Keluarga 3, no. 1 (2017): 20-28.
} 
atau peserta Sekolah Minggu. Kegiatan ini dilaksanakan untuk anak sejak usia dini, supaya lebih memahami Alkitab dan nilai Kristen secara mendalam. ${ }^{8}$ Oleh sebab itu, dalam suatu kegiatan Sekolah Minggu peserta harus memiliki perhatian penuh atau konsentrasi penuh atas setiap kegiatan yang terjadi di dalam serangkaian Sekolah Minggu. Namun pada praktiknya, peserta dalam kegiatan Sekolah Minggu kurang memiliki perhatian terhadap setiap rangkaian kegiatan, khususnya saat penyampaian firman Tuhan oleh guru Sekolah Minggu. Hal ini terjadi akibat peserta Sekolah Minggu kurang mampu menyimak, sehingga cerita yang disampaikan kurang dipahami atau bahkan tidak dipahami. Peserta Sekolah Minggu kelas pratama GKII Bukit Moria Kasongan memiliki kelemahan dalam menyimak, sehingga tingkat pemahaman mereka terhadap cerita Alkitab juga kurang. Sehingga penulis berupaya meneliti bagaimana guru Sekolah Minggu GKII Bukit Moria Kasongan melakukan pemecahan masalah terkait kasus ini. Salah satu upaya yang dilakukan oleh guru-guru adalah dengan mencoba menerapkan model belajar storytelling. Pemilihan model ini juga disebabkan kondisi pada saat itu, cerita yang dipilih adalah cerita yang perlu melibatkan emosi dan intonasi, sehingga penting bagi guru untuk menyampaikannya kepada peserta Sekolah Minggu, yaitu dengan bercerita atau dengan model storytelling. Dengan demikian, penulis memandang perlu diteliti penerapan storytelling dalam menceritakan kisah Alkitab pada anak Sekolah Minggu kelas pratama di GKII Bukit Moria Kasongan.

Permasalahan dalam penelitian ini yaitu bagaimanakah penerapan storytelling dalam menceritakan kisah Alkitab pada anak Sekolah Minggu kelas pratama di GKII Bukit Moria Kasongan? Tujuan penelitian ini adalah untuk memaparkan penerapan storytelling dalam menceritakan kisah Alkitab pada anak Sekolah Minggu. Manfaat dari penelitian ini diharapkan dapat membantu dalam pengembangan pendidikan terutama di Sekolah Minggu kelas pratama di GKII Bukit Moria Kasongan.

\section{Metode Penelitian}

Pendekatan penelitian yang digunakan dalam penelitian ini adalah penelitian kualitatif. Pendekatan kualitatif menurut Purwanto dapat digunakan untuk memahami sebuah permasalahan dan proses perbaikan. Dalam konteks pembinaan warga gereja, penilitian ini dapat membantu memberikan informasi yang dapat mengembangkan pelayanan gereja. ${ }^{9}$ Penelitian ini dilaksanakan di Sekolah Minggu kelas pratama GKII Bukit Moria Kasongan. Pertimbangannya karena guru-guru Sekolah Minggu kelas pratama GKII Bukit Moria Kasongan melakukan upaya perbaikan dengan melaksanakan pembelajaran model storytelling. Dalam observasi, penulis mengamati proses pembelajaran yang dilakukan oleh guru sesuai dengan rencana pembelajaran. Hasil observasi kemudian didiskusikan dengan guru, sehingga dihasilkan sebuah refleksi dari hasil pembelajaran. Pola yang penulis gunakan memiliki kemiripan dengan pendekatan lesson study. Jadi dalam hal ini penulis melakukan

\footnotetext{
${ }^{8}$ I Putu Ayub Darmawan, Dasar-Dasar Mengajar Sekolah Minggu (Ungaran: Sekolah Tinggi Teologi Simpson, 2016), 14.

${ }^{9}$ Hary Purwanto, "Manfaat Penelitian Untuk Perkembangan Gereja," in Prosiding Seminar Nasional Pendidikan Agama Kristen STT Simpson Tahun 2016 Tema: Strategi Pembinaan Jemaat Untuk Meningkatkan Kehidupan Jemaat (presented at the Seminar Nasional Pendidikan Agama Kristen \& call for papers, Ungaran: Sekolah Tinggi Teologi Simpson, 2016).
} 
observasi kemudian mendiskusikan hasil observasi dengan guru yang mengajar sehingga ada pengalaman dari hasil penelitian bagi guru. Hasil yang diperoleh dari proses ini adalah apakah ada kemajuan dalam upaya dan implementasi pemecahan masalah dalam pembelajaran.

Instrumen obeservasi terhadap proses pembelajaran terdiri dari beberapa aspek meliputi 1) Kondisi kelas yang tenang, 2) Guru menyampaikan cerita sesuai dengan rencana pembelajaran, 3) Murid memperhatikan cerita yang disampaikan guru, 4) Murid antusias memberikan respon terhadap pertanyaan yang diajukan oleh guru, 5) Murid secara efektif menceritakan kembali kisah Alkitab yang diceritakan oleh guru. Kriteria keberhasilan menceritakan kembali kisah Alkitab oleh anak Sekolah Minggu dalam pembelajaran dengan storytelling adalah 1) Kesesuaian cerita dengan cerita yang disampaikan oleh guru, 2) Kemampuan untuk menceritakan kembali dengan kalimat sederhana, penggunaan kosa kata baru, atau bercerita dalam bahasa sendiri, 3) Kelancaran dalam menceritakan kembali kisah Alkitab sesuai dengan topik cerita, 4) Ketepatan untuk mengungkapkan makna cerita yang dipahami oleh murid berdasarkan cerita yang disampaikan oleh guru.

Proses pengumpulan data dilakukan dengan obervasi dan diskusi terarah. Dalam melakukan observasi, penulis menggunakan panduan observasi yang terdiri dari langkahlangkah pelaksanaan, kemudian penulis menggunakan rencana pembelajaran yang guru telah susun sehingga dapat menjadi acuan dalam observasi. Hasil observasi dan diskusi terarah yang penulis lakukan kemudian dianalisis dengan melakukan pengelompokan data dan mendisplainya secara deskriptif. Penulis juga melakukan triangulasi dengan membandingkan hasil observasi dengan informasi guru yang diperoleh dalam diskusi terarah.

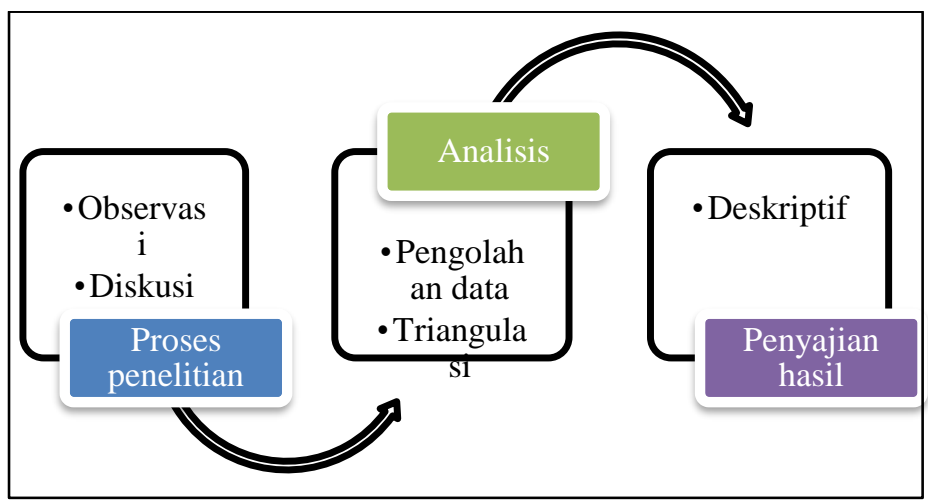

Gambar 1: Proses Penelitian

\section{Strategi Pemecahan Masalah dengan Menggunakan Storytelling}

Permasalahan pada kegiatan pembelajaran di Sekolah Minggu sebagaimana dikemukakan pada bagian pendahuluan dipecahkan dengan menggunakan storytelling. Sekolah Minggu kelas pratama GKII Bukit Moria Kasongan memiliki kelemahan dalam menyimak, sehingga tingkat pemahaman mereka terhadap cerita Alkitab juga kurang. Strategi pemecahan masalah rendahnya kemampuan menyimak dan memahami cerita Alkitab yang digunakan guru adalah penugasan menceritakan kembali cerita yang telah disampaikan oleh guru Sekolah Minggu. Berdasarkan sintak storytelling, akhir dari seluruh kegiatan pelaksanaannya, anak Sekolah Minggu kembali menceritakan cerita yang telah disampaikan guru dengan bahasa sendiri di depan kelas. Alasan pemilihan strategi pemecahan masalah rendahnya kemampuan menyimak 
dan memahami cerita Alkitab adalah penugasan menceritakan kembali cerita yang telah disampaikan oleh guru sekolah. Strategi itu digunakan karena penugasan menceritakan kembali merupakan sintak akhir dari model pembelajaran storytelling. Tahap tersebut dilakukan untuk mengevaluasi dan meninjau keberhasilan capaian anak Sekolah Minggu, apakah anak telah berhasil mengembangkan kemampuan menyimak, apakah anak telah berhasil memahami sepenuhnya isi cerita. Melalui penugasan menceritakan kembali, guru dapat dengan mudah menilai tingkat keberhasilan anak. Kefasihan anak menceritakan kembali dengan bahasa sendiri, merupakan capaian keberhasilan storytelling.

Implementasi strategi pemecahan masalah rendahnya kemampuan menyimak dan memahami cerita adalah penugasan menceritakan kembali cerita Alkitab yang telah disampaikan guru. Sebelum melihat kepada implementasi pemecahan masalah, penulis terlebih dahulu menguraikan langkah-langkah model pembelajaran storytelling.

Tabel 1: Langkah-Langkah Pelaksanaan

\begin{tabular}{|c|c|c|}
\hline $\begin{array}{c}\text { Langkah- } \\
\text { Langkah } \\
\text { Pembelajaran }\end{array}$ & Kegiatan Guru & Kegiatan Peserta Didik \\
\hline Fase 1 & $\begin{array}{l}\text { Guru menyampaikan tujuan dan } \\
\text { mempersiapkan anak untuk mendengar dan } \\
\text { menyimak cerita yang akan disampaikan } \\
\text { guru. }\end{array}$ & $\begin{array}{l}\text { Anak menyimak penjelasan guru dan } \\
\text { mempersiapkan diri baik secara fisik } \\
\text { maupun secara mental. }\end{array}$ \\
\hline Fase 2 & $\begin{array}{l}\text { Guru mengajukan beberapa pertanyaan } \\
\text { kepada anak yang mengarah pada cerita. }\end{array}$ & Anak menjawab pertanyaan guru. \\
\hline Fase 3 & $\begin{array}{l}\text { Guru menceritakan cerita Alkitab dengan } \\
\text { lafal, intonasi dan ekspresi sesuai cerita. }\end{array}$ & $\begin{array}{l}\text { Anak mendengar, menyimak dan } \\
\text { memperhatikan guru yang sedang } \\
\text { bercerita. }\end{array}$ \\
\hline Fase 4 & $\begin{array}{l}\text { Guru memastikan anak menyimak cerita } \\
\text { dengan menanyakan pertanyaan-pertanyaan } \\
\text { terkait cerita. }\end{array}$ & Anak menjawab pertanyaan guru. \\
\hline Fase 5 & $\begin{array}{l}\text { Untuk lebih meyakinkan kemampuan } \\
\text { menyimak anak, guru menanyakan } \\
\text { pertanyaan kepada anak yang ditunjuk secara } \\
\text { acak berkaitan dengan cerita. }\end{array}$ & $\begin{array}{l}\text { Masing-anak anak mempersiapkan diri } \\
\text { dan mempersiapkan jawaban untuk } \\
\text { menjawab pertanyaan guru. }\end{array}$ \\
\hline Fase 6 & $\begin{array}{l}\text { Guru memberikan pengakuan dan } \\
\text { penghargaan terhadap usaha dan prestasi } \\
\text { anak dalam kemampuannya menjawab } \\
\text { pertanyaan terkait. }\end{array}$ & $\begin{array}{l}\text { Anak menerima pengakuan dan } \\
\text { penghargaan guru. }\end{array}$ \\
\hline Fase 7 & $\begin{array}{l}\text { Guru menunjuk beberapa anak untuk } \\
\text { menceritakan kembali cerita yang telah } \\
\text { disampaikan oleh guru. }\end{array}$ & $\begin{array}{l}\text { Beberapa anak yang telah ditunjuk } \\
\text { mempersiapkan diri dan maju ke depan } \\
\text { kelas untuk menceritakan ulang cerita } \\
\text { dengan bahasa sendiri, sementara anak } \\
\text { yang lain memperhatikan sambil } \\
\text { menyimak cerita temannya. }\end{array}$ \\
\hline
\end{tabular}

Kemudian, proses penugasan menceritakan kembali cerita Alkitab yang telah disampaikan guru sebagai implementasi strategi pemecahan masalah rendahnya kemampuan menyimak dan memahami cerita: 1) Anak mempersiapkan diri dengan mengingat kembali cerita melalui menjawab pertanyaan-pertanyaan guru Sekolah Minggu yang berkaitan dengan cerita; 2) Anak ditunjuk dan maju ke depan kelas dengan mantap; 3) Anak menceritakan ulang cerita Alkitab dengan bahasa sendiri, sementara teman yang lain mendengarkan. 
Sintaks yang digunakan oleh guru Sekolah Minggu di GKII Bukit Moria Kasongan sesuai dengan sitaks yang umumnya digunakan. Hal ini penulis bandingkan dengan tulisan Rahmawati, walau sintaks Rahmawati tampaknya ada sedikit modifikasi. Penulis juga membandingkannya dengan sintaks yang digunakan oleh Pratiwi. ${ }^{10}$ Hanya memang setiap guru yang menggunakan metode ini melakukan modifikasi agar relevan dengan cerita dan pembelajaran yang dilaksanakan. Beberapa contoh yang melakukan modifikasi adalah dengan menggunakan bantuan boneka tangan, lagu, gambar, dan audio visual. Modifikasi ini masingmasing membantu untuk meningkatkan kemampuan menyimak, mendengar, dan menceritakan kembali. Beberapa penelitian telah menunjukkan bahwa hal itu berhasil dan membantu memecahkan masalah. ${ }^{11}$ Dengan demikian dalam implementasi di Sekolah Minggu GKII Bukit Moria Kasongan, guru dapat melakukan modifikasi dan pengembangan sehingga dapat meningkatkan proses dan hasil pembelajaran. Setyarini menjelaskan bahwa model pembelajaran storytelling adalah kegiatan pembelajaran yang dirancang agar peserta didiknya tidak hanya mendengar melainkan terlibat dalam kegiatan pembelajaran. ${ }^{12}$ Pengertian ini sejalan dengan sintak akhirnya yaitu memberi kesempatan kepada anak untuk menceritakan kembali dengan bahasa sendiri. Hal ini berarti tidak hanya menuntut anak untuk menyimak dan memahami tetapi juga mengingat cerita supaya ia dapat menceritakannya kembali. Ini juga berarti, anak harus memiliki pemahaman yang tinggi terhadap cerita, karena jika tidak memahami cerita, tentu anak tidak akan dapat menceritakan kembali dengan bahasa sendiri. Untuk dapat memahami cerita dengan baik, maka anak harus menyimak cerita yang disampaikan. Maka, tujuan daripada storytelling ini yaitu untuk meningkatkan kemampuan menyimak dan memahami cerita.

\section{Hasil dan Pembahasan}

\section{Hasil yang Dicapai}

Penerapan storytelling dalam menceritakan kisah Alkitab pada anak Sekolah Minggu di GKII Bukit Moria Kasongan, mencapai hasil setelah melakukan penugasan menceritakan ulang cerita yang telah disampaikan oleh guru. Dalam penelitian ini, ada 11 anak Sekolah Minggu yang terlibat dalam pembelajaran dengan model storytelling. Pada pertemuan pertama, kisah Alkitab yang diceritakan adalah perumpamaan tentang seorang penabur dari Matius 13:1-9. Pertemuan kedua kisah Alkitab yang diceritakan adalah kisah tentang kesepuluh orang kusta

\footnotetext{
${ }^{10}$ Afiani Rahmawati, "Peningkatan Keterampilan Menyimak Dongeng Melalui Model Paired Storytelling Dengan Media Wayang Kartun Pada Siswa Kelas II SDN Mangunsari Semarang” (other, Universitas Negeri Semarang, 2013), accessed January 7, 2020, https://ib.unnes.ac.id/19365/; Rosalina Rizki Pratiwi, "Penerapan Metode Storytelling Untuk Meningkatkan Keterampilan Berbicara Siswa Kelas II SDN S4 Bandung," Jurnal Pendidikan Guru Sekolah Dasar 1, no. 1 (2016): 199-207.

${ }^{11}$ Rahmawati, "Peningkatan Keterampilan Menyimak Dongeng Melalui Model Paired Storytelling Dengan Media Wayang Kartun Pada Siswa Kelas II SDN Mangunsari Semarang”; Eko Santoso, "Peningkatan Keterampilan Berbicara Melalui Metode Storytelling (Bercerita) Dengan Menggunakan Boneka Tangan Pada Mata Pelajaran Bahasa Indonesia Siswa Kelas V SD Negeri Teloyo 3 Tahun Ajaran 2012/2013" (s1, Universitas Muhammadiyah Surakarta, 2013), accessed January 7, 2020, http://eprints.ums.ac.id/23635/; Elnida Saldaria, "Peningkatan Keterampilan Berbicara Melalui Metode Storytelling Berbantuan Big Book" (masters, Universitas Pendidikan Indonesia, 2017), accessed January 7, 2020, http://repository.upi.edu.

${ }^{12}$ Sri Setyarini, "Pengembangan Model Pembelajaran Berbasis Storytelling: Sebuah Terobosan Dalam Upaya Meningkatkan Output Pembelajaran Bahasa Inggris Anak Usia Dini,” Jurnal Penelitian Pendidikan 15, no. 2 (2015): 1-8.
} 
dari Lukas 17:11-19. Pada pertemuan ketiga guru menceritakan kisah Alkitab tentang Yesus memberi makan lima ribu orang dari Matius 14:13-21. Lalu pada pertemuan keempat kisah Alkitab yang diceritakan adalah kisah dalam Markus 5:1-20 tentang Yesus yang mengusir Roh Jahat di Gerasa. Rata-rata waktu yang digunakan oleh guru untuk menyampaikan kisah Alkitab adalah 10 menit. Pada pertemuan pertama, kedua, ketiga dan keempat di masingmasing pertemuan ada 4-5 anak yang diminta untuk menceritakan kembali cerita yang telah mereka dengar. Jadi dalam empat pertemuan tersebut ada anak yang memperoleh kesempatan dua kali untuk menceritakan cerita yang mereka dengar dari pembelajaran dengan storytelling. Setiap anak memperoleh kesempatan menceritakan kembali kisah Alkitab maksimum 5 menit sebagaimana fase 7 dalam tabel di atas.

Hasil yang dicapai, yaitu: 1) Meningkatnya kemampuan memahami pada anak, terbukti dari keberhasilan menceritakan kembali cerita, secara khusus cerita Alkitab. Tingkat keberhasilan kemampuan memahami cerita dibuktikan dari berhasilnya anak menceritakan kembali cerita. Setelah mendengar lafal dan intonasi serta ekspresi pencerita, anak yang menyimak tentu dapat mencerna dan mengingat cerita dengan baik sesuai dengan yang disampaikan pencerita. Sehingga keberhasilan menceritakan kembali menunjukkan meningkatnya kemampuan menyimak pada anak; 2) Meningkatnya kemampuan mendengar pada anak. Dengan menyimak cerita yang disampaikan, anak melatih diri untuk menjadi pendengar yang cermat. Dalam model storytelling, pendengar atau peserta yang mengikuti harus mendengar dengan baik supaya dapat memahami cerita dengan benar. Jika tidak, maksud dan pesan dari cerita tidak dapat dipahami; 3) Meningkatnya kemampuan mengingat, sehingga dapat menceritakan kembali. Menceritakan kembali juga menunjukkan bahwa anak mampu mengingat; 4) Meningkatnya kemampuan menyimak pada anak. Anak dapat berkonsentrasi untuk menyimak cerita guru. Hal ini penting, karena dengan menyimak cerita, pendengar dapat mengingat tokoh, latar dan situasi dalam cerita bahkan setiap detail cerita yang disampaikan dapat dipahami dengan benar. Hasil yang dicapai oleh guru Sekolah Minggu sejalan dengan penelitian yang dilakukan oleh Hasanah, Harmawati, dan Hidayat. Hasil penelitian Hasanah, Harmawati, dan Hidayat juga menunjukkan bahwa melalui penggunaan storytelling anak-anak dapat terbantu untuk menyimak cerita kemudian menceritakan kembali apa yang telah didengar. Walau demikian menurut Hasanah, Harmawati, dan Hidayat anak-anak perlu bantuan untuk dapat menyusun kembali cerita dalam bahasa mereka sendiri. Faktornya adalah masih minimnya kosakata anak. ${ }^{13}$ Sama halnya dengan anak-anak di GKII Bukit Moria Kasongan, beberapa anak perlu bantuan guru agar dapat menceritakan kembali kisah Alkitab dihadapan teman-temannya. Jika demikian maka dalam implementasi metode ini perlu pertimbangan yang matang dalam memilih cerita atau guru dapat membagi cerita dalam beberapa babak. Faktor tersebut tidak lepas dari masa perkembangan anak yang umumnya masih pemalu, minimnya kosakata, dan ingatan mereka

\footnotetext{
${ }^{13}$ Nurlayli Hasanah, Diah Harmawati, and Afif Khoirul Hidayat, "Meningkatkan Kemampuan Berbicara Melalui Kegiatan Bercerita Berbantu Media Finger Puppet Pada Anak Kelompok B," Musamus Journal of Primary Education 2, no. 1 (2019): 32-37.
} 
belum cukup kuat terutama pada cerita yang baru didengar. ${ }^{14}$ Tetapi ketika penulis memperhatikan penelitian Nurmiati maka jika penggunaan storytelling terus digunakan untuk menceritakan sebuah kisah maka akan membantu anak mengembangkan kemampuan berbahasa dan berbicaranya. ${ }^{15}$ Itu artinya penerapan model pembelajaran ini perlu diimplementasikan secara berkelanjutan dan dapat dilakukan modifikasi sintaks agar tidak monoton.

\section{Kendala Yang Dihadapi}

Selain berhasil mencapai beberapa hal di atas, ada beberapa kendala yang dihadapi dalam pelaksanaan storytelling dan dalam penugasan menceritakan kembali. Kendala tersebut, yaitu: 1) Anak Sekolah Minggu kelas pratama GKII Bukit Moria Kasongan adalah anak-anak yang aktif dan berkonsentrasi pendek, sehingga harus meminimalis waktu bercerita supaya anak tidak hilang konsentrasi. Hasil observasi menunjukkan bahwa ada murid yang cenderung tertarik untuk mengganggu temannya ketika cerita mendekati menit kesepuluh. Hasil diskusi dengan beberapa guru yang mengamati menunjukkan bahwa konsentrasi anak mulai hilang ketika cerita disampaikan terlalu panjang. Masalah ini menang tidak terjadi pada semua murid, tetapi pada murid-murid yang cenderung sejak awal memiliki konsentrasi yang pendek. Hal ini juga berkaitan dengan pemilihan cerita, apakah cerita yang dipilih adalah cerita yang panjang atau cerita yang pendek. Jika memilih cerita yang panjang dengan kondisi peserta atau anak yang berkonsentrasi pendek, maka akan mengalami kesulitan.

Oleh sebab itu, dalam hal ini dilakukan pemilihan cerita yang pendek, supaya memiliki waktu yang cukup untuk menceritakannya kepada anak. Namun, sekalipun telah memilih cerita yang pendek, penerapan storytelling dengan menggunkan lafal, intonasi dan ekspresi tetap memakan waktu yang cukup lama. Sehingga beberapa anak yang berkonsentrasi pendek memilih untuk bermain sendiri dan tidak memperhatikan cerita dengan cermat. 2) Kurangnya kepercayaan diri anak untuk bercerita di depan kelas, sehingga guru berusaha keras untuk mendorong anak supaya berani bercerita dengan bahasa sendiri. Kepercayaan diri berkaitan dengan mental dan dorongan, guru-guru bekerja keras untuk bisa mendorong anak yang sebenarnya memiliki kemampuan mengingat cerita yang baik tetapi kurang percaya diri menceritakan kembali. Kendala semacam ini memang akan ditemui dalam penerapan model storytelling karena sintak akhir adalah peserta menceritakan kembali, jika hal ini tidak tercapai, belum dapat dipastikan bahwa anak mengerti cerita dengan baik, kemungkinan juga anak tidak mendengar dan menyimak cerita. Kendala-kendala yang terjadi pada Sekolah Minggu GKII Bukit Moria Kasongan juga terjadi di beberapa tempat lainnya. Penyelesaiannya dapat dilakukan dengan memperhatikan tingkat kognitif anak-anak dan pemilihan cerita. Hal ini sesuai dengan penelitian yang dilakukan oleh Ariyani dan Hariyono.

\footnotetext{
${ }^{14}$ Elizabeth B. Hurlock, Developmental Psychology, McGraw-Hill series in psychology (New York: McGraw-Hill Book, 1953), 104.

${ }^{15}$ Nurmiati Nurmiati, "Meningkatkan Kemampuan Bahasa Melalui Metode Bercerita Pada Anak Usia Dini Di TK," ECEIJ (Early Childhood Education Indonesian Journal) 1, no. 1 (2018): 27-32.
} 
Dalam jurnalnya, Ariyani dan Hariyono menyarankan dalam implementasi metode ini guru perlu terlebih dahulu mencermati perkembangan kognitif dan minat anak pada cerita. ${ }^{16}$

Faktor-faktor yang mendukung pengembangan kemampuan menyimak dan memahami cerita pada anak melalui penugasan menceritakan kembali cerita yang telah disampaikan guru, yaitu: 1) Anak-anak antusia mendengar cerita atau memiliki minat yang tinggi untuk mendengar cerita guru. Hasil observasi dan diskusi terarah dengan guru menunjukkan bahwa ketika kisah Alkitab disampaikan dengan storytelling membuat kisah Alkitab menjadi menarik didengar. Tampaknya hal ini menarik perhatian murid. Penggunaan intonasi suara, alur cerita yang menarik, dan dalam bahasa yang sederhana menyebabkan anak-anak tertarik mendengar cerita. Hasil observasi penulis menunjukkan bahwa bukti dari anak-anak antusias mendengar cerita adalah mereka duduk tenang, walau ada anak yang hilang konsentrasi menjelang menit kesepuluh tetapi secara keseluruhan perhatian mereka pada cerita cukup kuat. Ketika guru memulai cerita, tampak anak-anak mulai menyiapkan posisi yang tampak mau mendengarkan cerita; 2) Pengawasan dan dukungan dari pihak pembimbing guru Sekolah Minggu, yaitu ibu gembala GKII Bukit Moria Kasongan yang mendampingi dalam berjalannya kegiatan Sekolah Minggu dan selama pelaksanaan storytelling oleh guru. Hasil observasi penulis menunjukkan bahwa ada pendampingan dari ibu gembala kepada guru-guru Sekolah Minggu. Hal ini tampaknya menjadi dorongan bagi para guru dan sebagai bentuk supervisi sehingga dapat melaksanakan pembelajaran dengan baik. Tindak lanjut pengembangan kemampuan menyimak dan memahami cerita ini yaitu dengan menerapkan secara berulang model storytelling dalam kesempatan lain mengajar Sekolah Minggu. Dapat juga dengan pengadaan reward bagi anak yang mampu menceritakan kembali cerita, sehingga anak termotivasi untuk menyimak dan berusaha memahami cerita untuk diceritakan ulang kepada teman-temannya atas dorongan motivasi reward. Faktor-faktor pendukung di atas dapat juga membantu untuk meningkatkan terjadinya pemecahan masalah di Sekolah Minggu GKII Bukit Moria Kasongan.

Dari hasil penelitian dan pembahasan di atas maka menurut penulis, metode pembelajaran storytelling yang menceritakan kisah Alkitab dengan menggunakan kalimat sederhana dapat membantu untuk meningkatkan kemampuan menyimak, mendengar, mengingat, dan memahami. Dalam proses selanjutnya terjadi proses memorisasi, dimana terjadi perekaman, penyimpanan, pemahaman, dan pemanggilan kembali. Hasil dari proses yang terjadi pada diri anak kemudian membantunya untuk berbicara dan menceritakan kembali cerita yang telah didengarnya.

\footnotetext{
${ }^{16}$ Lita Ariani and Dyta Setiawati Hariyono, "Storytelling Sebagai Metode Dalam Mengembangkan Kemampuan Berbahasa Pada Anak Prasekolah," in Prosiding Seminar Nasional \& Call Paper Psikologi Pendidikan 2019 (presented at the Seminar Nasional \& Call Paper Psikologi Pendidikan 2019 Fakultas Pendidikan Psikologi, Malang: Universitas Negeri Malang, 2019), 36-44.
} 


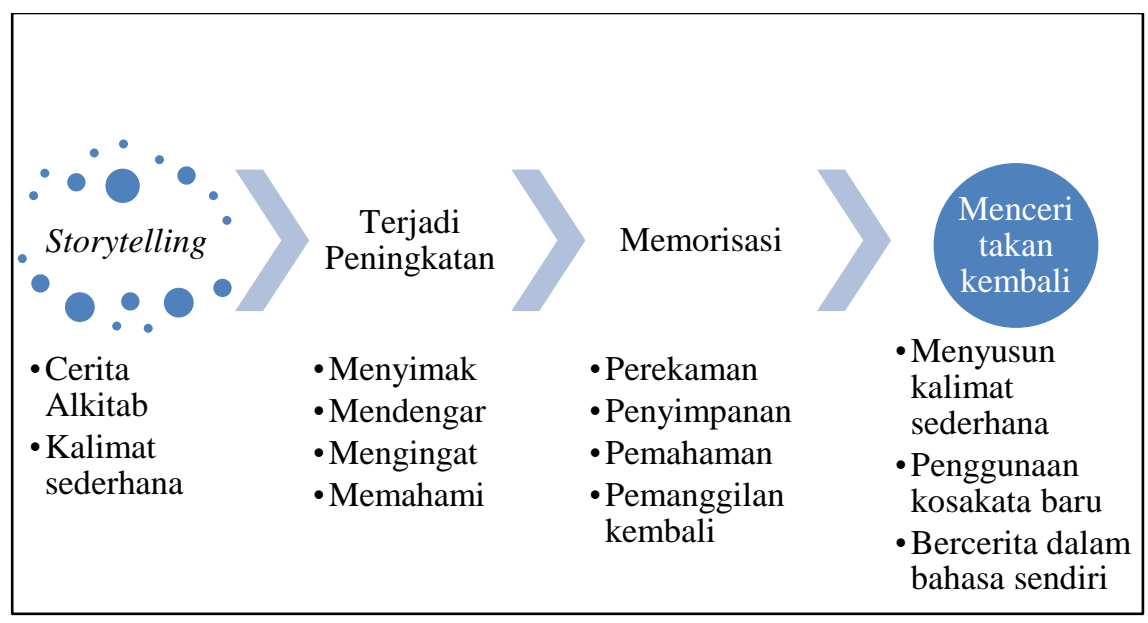

Gambar 2: Proses anak dapat menceritakan kembali

Dalam upaya terus meningkatkan ingatan pada anak, sebagai bagian dari proses memorisasi guru dapat melakukan pengulangan. Pengulangan memiliki peran untuk terjadinya perekaman dalam jumlah yang banyak, sehingga membantu anak untuk memiliki ingatan yang cukup banyak pada satu topik dan akhirnya memudahkannya untuk memanggil kembali. Konsep ini sesuai dengan kajian Darmawan terhadap pembelajaran memorisasi berdasarkan Ulangan 6:69. ${ }^{17}$ Dalam model pembelajaran ini, guru perlu terus melakukan konfirmasi pada anak dengan meminta mereka menceritakan kembali dan guru membantu mereka dengan mengingatkan beberapa bagian yang mungkin kurang diingat oleh anak.

\section{Kesimpulan}

Melalui penerapan ceramah berbantuan storytelling, maka anak akan semakin berupaya mengembangkan diri untuk menyimak disertai memahami cerita. Kemampuan tersebut terlihat dari kemampuan anak dalam menceritakan ulang cerita dengan bahasa sendiri. Penerapan model pembelajaran storytelling ini terhadap anak Sekolah Minggu kelas pratama GKII Bukti Moria Kasongan merupakan teknik yang tepat agar melatih anak berbicara dan menceritakan kisah Alkitab. Dampak atau hasil dari pada penugasan akhir kepada anak membuat anak terpacu untuk lebih berkonsentrasi dalam mendengar, menyimak cerita guru dan berusaha memahaminya.

Rekomendasi yang diberikan berdasarkan hasil pengembangan kemampuan menyimak dan memahami cerita melalui model pembelajaran storytelling yaitu sebaiknya pihak orang tua dapat melatih anak untuk memiliki kemampuan menyimak melalui storytelling. Model pembelajaran ini dapat orang tua lakukan di rumah. Anak tidak perlu menunggu hari Minggu supaya mendengar cerita Alkitab, karena sebetulnya orang tua memegang andil yang penuh untuk mengajar anak-anak dalam pemahaman terhadap cerita Alkitab.

${ }^{17}$ I Putu Ayub Darmawan, "Pembelajaran Memorisasi dalam Ulangan 6:6-9," EPIGRAPHE: Jurnal Teologi dan Pelayanan Kristiani 3, no. 1 (2019): 25-31; Kurt Danziger, Marking the Mind: A History of Memory (New York, NY, US: Cambridge University Press, 2009); Thomas E. Scruggs and Margo A. Mastropieri, "Mnemonic Instruction of LD Students: A Field-Based Evaluation,” Learning Disability Quarterly 12, no. 2 (1989): 119125. 


\section{Refrensi}

Anggrayeni, Ni Komang, Ni Ketut Suarni, and Didith Pramunditya Ambara. "Penerapan Metode Bercerita Berbantuan Media Audio Visual Untuk Meningkatkan Keterampilan Berbicara Anak.” Jurnal Pendidikan Anak Usia Dini Undiksha 3, no. 1 (2015). Accessed January 4, 2020. https://ejournal.undiksha.ac.id/index.php/JJPAUD/article/view/5896.

Anjani, Ketut Sri, I. Nyoman Wirya, and I. Gde Wawan Sudatha. "Penerapan Metode Bercerita Berbantuan Media Papan Flanel Untuk Meningkatkan Kemampuan Kognitif Pada Anak Kelompok A Di PAUD Pradnya Paramita." Jurnal Pendidikan Anak Usia Dini Undiksha 1, no. 1 (2013): 1-10.

Ariani, Lita, and Dyta Setiawati Hariyono. "Storytelling Sebagai Metode Dalam Mengembangkan Kemampuan Berbahasa Pada Anak Prasekolah." In Prosiding Seminar Nasional \& Call Paper Psikologi Pendidikan 2019, 36-44. Malang: Universitas Negeri Malang, 2019.

Ayuni, Rita Diah, S. Siswati, and Diana Rusmawati. "Pengaruh Storytelling Terhadap Perilaku Empati Anak.” Jurnal Psikologi 12, no. 2 (2013): 121-130.

Danziger, Kurt. Marking the Mind: A History of Memory. New York, NY, US: Cambridge University Press, 2009.

Darmawan, I Putu Ayub. Dasar-Dasar Mengajar Sekolah Minggu. Ungaran: Sekolah Tinggi Teologi Simpson, 2016.

_. "Pembelajaran Memorisasi dalam Ulangan 6:6-9." EPIGRAPHE: Jurnal Teologi dan Pelayanan Kristiani 3, no. 1 (2019): 25-31.

Faridawati, Ria, Cucu Eliyawati, and Rudiyanto Rudiyanto. "Meningkatkan Kemampuan Berbicara Anak Usia Dini Melalui Metode Bercerita Menggunakan Media Hasil Karya Anak." Edukids: Junal Pertumbuhan, Perkembangan, dan Pendidikan Anak Usia Dini 14, no. 1 (2017): 208-213.

Hasanah, Nurlayli, Diah Harmawati, and Afif Khoirul Hidayat. "Meningkatkan Kemampuan Berbicara Melalui Kegiatan Bercerita Berbantu Media Finger Puppet Pada Anak Kelompok B.” Musamus Journal of Primary Education 2, no. 1 (2019): 32-37.

Hurlock, Elizabeth B. Developmental Psychology. McGraw-Hill series in psychology. New York: McGraw-Hill Book, 1953.

Ningsih, Suwarti. "Peningkatan Keterampilan Berbicara Melalui Metode Bercerita Siswa Kelas III SD Negeri 1 Beringin Jaya Kecamatan Bumi Raya Kabupaten Morowali." Jurnal Kreatif Online 2, no. 4 (2015): 243-256.

Nurmiati, Nurmiati. "Meningkatkan Kemampuan Bahasa Melalui Metode Bercerita Pada Anak Usia Dini Di TK.” ECEIJ (Early Childhood Education Indonesian Journal) 1, no. 1 (2018): 27-32.

Permatasari, Andalusia Neneng, Dinar Nur Inten, Dewi Mulyani, and Nan Rahminawati. "Literasi Dini Dengan Teknik Bercerita." FamilyEdu: Jurnal Pendidikan Kesejahteraan Keluarga 3, no. 1 (2017): 20-28.

Pratiwi, Rosalina Rizki. "Penerapan Metode Storytelling Untuk Meningkatkan Keterampilan Berbicara Siswa Kelas II SDN S4 Bandung." Jurnal Pendidikan Guru Sekolah Dasar 1, no. 1 (2016): 199-207.

Purwanto, Hary. "Manfaat Penelitian Untuk Perkembangan Gereja." In Prosiding Seminar Nasional Pendidikan Agama Kristen STT Simpson Tahun 2016 Tema: Strategi Pembinaan Jemaat Untuk Meningkatkan Kehidupan Jemaat. Ungaran: Sekolah Tinggi Teologi Simpson, 2016.

Rahmawati, Afiani. "Peningkatan Keterampilan Menyimak Dongeng Melalui Model Paired Storytelling Dengan Media Wayang Kartun Pada Siswa Kelas II SDN Mangunsari Semarang." Other, Universitas Negeri Semarang, 2013. Accessed January 7, 2020. https://lib.unnes.ac.id/19365/. 
Safira, Alifia Nur, Putu Nanci Riastini, and I Ketut Dibia. "Pengaruh Teknik Pembelajaran Storytelling Berbantuan Satua Bali Terhadap Keterampilan Berbicara Pada Siswa Kelas V SD.” MIMBAR PGSD Undiksha 5, no. 2 (2017): 1-10.

Saldaria, Elnida. "Peningkatan Keterampilan Berbicara Melalui Metode Storytelling Berbantuan Big Book." Masters, Universitas Pendidikan Indonesia, 2017. Accessed January 7, 2020. http://repository.upi.edu.

Santoso, Eko. "Peningkatan Keterampilan Berbicara Melalui Metode Storytelling (Bercerita) Dengan Menggunakan Boneka Tangan Pada Mata Pelajaran Bahasa Indonesia Siswa Kelas V SD Negeri Teloyo 3 Tahun Ajaran 2012/2013.” S1, Universitas Muhammadiyah Surakarta, 2013. Accessed January 7, 2020. http://eprints.ums.ac.id/23635/.

Scruggs, Thomas E., and Margo A. Mastropieri. "Mnemonic Instruction of LD Students: A

Field-Based Evaluation.” Learning Disability Quarterly 12, no. 2 (1989): 119-125.

Setyarini, Sri. "Pengembangan Model Pembelajaran Berbasis Storytelling: Sebuah Terobosan Dalam Upaya Meningkatkan Output Pembelajaran Bahasa Inggris Anak Usia Dini." Jurnal Penelitian Pendidikan 15, no. 2 (2015): 1-8. 